\title{
KETERASINGAN DALAM UTOPIA CERPEN “ANTARA DEN HAAG DAN DELFT" KARYA RILDA A.OE TANEKO
}

\author{
Galuh Febri Putra \\ Alumni PBI UAD, Yogyakarta \\ Email: feb_putra08@yahoo.com
}

\begin{abstract}
Abstrak
Fokus tulisan ini adalah narasi keterasingan yang disebabkan oleh negara dalam cerpen "Antara Den Haag dan Delft" karya Rilda A.Oe Taneko. Negara merdeka yang hanya merupakan penulisan ulang dari apa yang telah direnggut oleh penjajah menciptakan fiksasi ruang dimana tidak bisa sertamerta mengakomodasi semua kepentingan. Keadaan itu memaksa tokoh kakek dalam cerpen untuk berimajinasi tentang ruang yang ideal di luar negara. Setelah tokoh kakek berada dalam utopia, dia malah merasa asing. Tulisan ini menggunakan teori pascakolonial Sara Upstone yang mengkonseptualkan bahwa negara sama dengan para pelaku kolonialisme, yaitu menutupi realita instabilitas yang terjadi di dalam ruang bernegara. Dalam praktik untuk meraih kemerdekaan, negara menggunakan panjipanji persatuan dalam perbedaan. Instabilitas memunculkan perjalanan menuju kota utopia dimana keterbatasan-keterbatasan yang dirasakan di tempat sebelumnya tidak akan pernah ada lagi. Tokoh kakek dalam cerpen ini merasa terasing di kota utopis karena penutupan instabilitas negara berupa kecintaan terhadap tanah air yang disematkan kepadanya. Apapun yang bukan menjadi bagian dari tanah airnya menjadi sesuatu yang asing dan aneh.
\end{abstract}

Kata kunci: keterasingan, utopia, cinta tanah air.

\begin{abstract}
This paper is focused on the alienation which caused by nation in Rilda A. Oe Taneko's short story entitled "Antara Den Haag dan Delft". Independent nation which is simply a rewriting of what has been taken away by the colonizer created fixation of space which can not accommodate all interests. This circumstance forced 'kakek' (an old man) in the short story to imagine the ideal space outside the nation. However, in the utopia kakeke feels alienated. This paper used the Postcolonial theory by Sara Upstone which conceptualize that the independent nation and colonizer do the same act, they just covered the instability in the space of nation. In the attempt to achieve independence, nation used the slogan unity in diversity. The instability led a journey to the utopia city where there is no limitations in place. Kakek. in the short story feels alienated in the utopia city because of the cover of instability in the form of his love to the nation that given to bim. Anything that is not a part of his nation turned into something strange.
\end{abstract}

Keywords: alienation, utopia, love to the nation.

\section{Pendahuluan}

Keterekaman negara dalam sastra Indonesia modern bisa dibilang sudah muncul sejak negara Indonesia belum merdeka. Dalam konteks waktu sebelum kemerdekaan, negara mandiri menjadi semacam mimpi bagi pelaku sastra yang merasa mengalami keterjajahan. Opresi yang dilakukan oleh penjajah Belanda melalui otoritas penerbitannya, yakni Balai Pustaka, memaksa para penulis melakukan negosiasi sehingga apa yang menjadi karyanya dapat diterbitkan secara mulus. Negara pada masa itu masih bersifat utopis yang hanya muncul dalam angan sehingga kebutuhan terhadap legitimasi geografi hanya muncul secara kedaerahan. Negara yang dinarasikan dalam novel-novel Balai Pustaka masih bersifat kedaerahan sehingga menjadikan karakter utama dalam narasi merasa terasing karena konstruksi rumah yang disebut dengan negara. Aprinus Salam (2003) dalam tulisannya yang dimuat dalam Jurnal Humaniora Volume XV No.1 menjelaskan terjadinya proses keterasingan tokoh utama dalam novel-novel Balai Pustaka seperti Siti Nurbaya dan Salah Asuban. Samsul Bahri dan Hanafi yang merupakan tokoh utama dalam novel tersebut menjadi tidak betah dan tidak cocok di lingkungan dan adat-istiadat dimana mereka berasal.

Pada angkatan '45 keterasingan 
karena negara dalam sastra nampaknya juga masih menjadi masalah yang muncul dalam narasi. Negara bagi para penulis periode ini menjadi sebuah candu kebebasan yang belum pernah dirasakan sebelumnya. Dari aroma surga yang diberikan oleh mimpi yang disebut sebagai "negara" itu, para penulis melakukan perlawanan mati-matian untuk merebut kemerdekaan melalui narasi yang lebih resisten terhadap penjajah daripada periode sebelumnya. Para penulis angkatan '45 seperti Chairil Anwar melakukannya dengan sajak-sajak Aku, Perjanjian dengan Bung Karno, Diponegoro, Siap Sedia, dan Karawang Bekasi. Karakter tulisan ekspresionisme dan realisme yang mengedepankan pengalaman batin yang membangun intensitas arti, membangun negara menjadi hal yang lebih bersifat sloganis. Slogan tentang negara kemudian oleh para penulis dibenturkan pada ruang realita sehingga memunculkan ruang eksploratif yang perlu untuk "ditemukan" atau "dibuat" hingga semua slogan dapat terpenuhi. Keterasingan yang muncul terhadap sesuatu akan memunculkan eksplorasi ruang untuk menemukan keidealan ruang yang disebut sebagai negara.

Jika dalam periode sebelumnya negara dan keterasingan dimunculkan untuk menemukan sebuah ruang yang ideal, dalam sastra Indonesia terkini negara sebagai pemicu keterasingan muncul akibat kemerdekaan hanyalah melakukan penulisan ulang, padahal Indonesia sebagai negara yang merdeka seharusnya sudah merupakan ruang yang ideal. Orang terjajah pada awalnya membangun negara sebagai sebuah rumah besar nan indah dan kokoh dari tanah kosong yang disebut dengan kemerdekaan itu. Bangunan negara tersebut dibangun dengan ciri dan corak dari sebuah bangsa yang membangunnya, sehingga bangsa lain tahu bahwa sebuah negara milik sebuah bangsa tertentu. Dalam bangunan negara juga terdapat kamar-kamar untuk memetakan dan memilah-milah anggota negara yang bersangkutan untuk mempermudah pengawasan. Tidak semua anggota negara sertamerta menyetujui kamar-kamar yang dibangun oleh negara tersebut karena mereka mungkin juga terjebak dalam kamar yang dibangun oleh negara yang tidak sesuai dengan harapan. Kehilangan akan ruang yang diharapkan menjadikan perasaan asing terhadap ruang yang telah disematkan oleh negara. Jika negosiasi ruang yang sudah tersemat tidak menemukan titik temu, keterasingan seseorang mungkin akan mendorong sebuah perjalanan ekploratif guna menemukan sebuah ruang yang ideal.

Sama seperti mimpi tentang negara yang dirasakan pada periode pra-kemerdekaan, dalam penulisan pasca-kemerdekaan yang tidak nyaman dengan penciptaan ruang negara dilakukan usaha-usaha untuk mendapatkan atau mencapai ruang yang menurut mereka ideal. Salah satu usaha yang paling lazim dimunculkan dalam narasi adalah "melarikan diri" menuju sebuah utopia yang mereka impikan. Perjalanan untuk mencapai utopia yang dilalui oleh tokoh yang bisa disebut wong kagol (orang yang tidak puas) tersebut bisa dibilang bukan merupakan perjalanan yang ringan ataupun pendek. Kemungkinan perjalanan mereka dimulai dari perjalanan batiniah dimana mereka membayangkan sebuah negeri atau kota ideal dimana mereka bisa menemukan kebebasan yang tidak dapat diberikan oleh negara. Kemudian barulah perjalanan fisik ke tempat itu dilakukan. Setelah sampai di negeri impian, perjalanan sejatinya belumlah usai, bahkan bisa dikatakan awal perjalanan yang sesungguhnya barulah dimulai.

Usaha penulisan dengan tokoh wong kagol seperti di atas juga dilakukan oleh penulis perempuan yang tinggal di luar negeri bernama Rilda A.Oe Taneko dalam cerpen "Antara Den Haag dan Delft" yang pertama kali dimuat di koran Tempo pada 3 Februari 2013. Cerpen ini menarasikan tokoh kakek sebagai orang yang melakukan perjalanan menuju kota yang utopis. Cerita cerpen ini ber-setting di Den Haag dan beberapa kota lain yang ada di Belanda. Alihalih mendapatkan ruang yang dianggap ideal, perjalanan tokoh kakek menuju kota utopia menimbulkan sebuah perasaan terasing terhadap diri kakek karena ruang yang telah disematkan 
negara padanya sebelum keberangkatan itu.

Seperti yang sudah dijelaskan di atas, negara yang dibangun di atas kemerdekaan sejatinya membuat identitas kenegaraan mereka agar berbeda dari negara lain, lebih-lebih dari negara yang dahulu menjajahnya. Dari sinilah sejatinya masalah dimulai, yakni negara setelah kemerdekaan biasanya berusaha menulis kembali apa saja yang telah direnggut oleh penjajah. Penulisan itu sejatinya dipaksakan agar sebuah negara memperoleh legitimasinya atau supaya mempermudah proses pengawasan. Apa yang dilakukan oleh negara tersebut jelas telah merenggut identitas dari rakyatnya dan menyematkan identitas baru yang disebut dengan bangsa. Dengan identitas kebangsaan itulah utopia yang diinginkan oleh tokoh kakek tersebut tidak serta-merta menerima mereka dan mungkin bahkan akan menolak mereka.

Penolakan yang dilakukan oleh sebuah utopia tidak lantas membuat tokoh kakek putus asa. Mereka pastinya akan melakukan daya dan upaya untuk dapat diterima oleh utopia tersebut. Usaha yang mereka lakukan pastilah melalui adaptasi sebab tidak mungkin untuk melakukan apropriasi karena sejatinya utopia yang mereka tuju pastilah lebih modern dan beradab daripada asal-usul negara mereka yang barbar. Adaptasi yang mereka lakukan pastilah dengan mencoba hidup seperti para warga utopia tersebut, misalnya memakai pakaian yang sama, memakan makanan mereka, ataupun dengan belajar bahasa mereka. Namun, hal ini juga menjadi semacam paradoks di tengah usaha mereka untuk diakui. Kegiatan yang mereka lakukan jelaslah berbeda dengan apa yang menjadi kebiasaannya, atau bahkan melawan nilai-nilai yang diterapkan oleh negara dimana mereka berasal, sehingga mereka merasa terasing dari apa yang mereka lakukan.

Keterasingan yang dirasakan oleh tokoh kakek kemungkinan didapati karena perbedaan ruang dan tempat atau mungkin juga konteks waktu. Negara sebagai pembebas dari kolonialisasi juga menanamkan semacam rantai kepada tubuh warganya yang notabene merupakan tempat yang paling privat. Rantai itu biasanya disebut dengan identitas kebangsaan, sehingga mempersempit ruang bagi warganya. Warga negara tertentu yang ingin bepergian ke luar negaranya harus menggunakan paspor sebagai izin tinggal di negara asing yang dituju. Paspor juga menunjukkan bahwa orang yang membawanya adalah orang asing dan bukan berasal dari negara yang ditempati. Selain batas yang ditentukan secara jelas, negara juga membuat batas-batas yang bersifat mistis atau kepercayaan. Sebagai contoh riil, Indonesia selalu mendoktrin warganya sebagai warga yang mempunyai sopan-santun, berbudi pekerti luhur, dan selalu menjunjung budaya ketimuran. Jelas dengan indoktrinasi seperti itu, orang Indonesia yang ada di luar negeri akan merasa asing dan aneh melihat budaya kumpulkebo yang ada di negara lain karena berlawanan dengan nilai yang ditanamkan oleh negaranya.

Untuk menjelaskan lebih lanjut tentang fenomena yang dirasakan sang tokoh kakek dalam cerpen "Antara Den Haag dan Delft" diperlukan konsep teoritis pascakolonial yang telah dibangun oleh Sara Upstone. Penggunaan konsep teoritis ini sejalan dengan masalah keterasingan yang disebabkan oleh negara sebagai sebuah ruang, dan juga ruang utopis yang menjadi sebuah titik awal perjalanan eksploratif.

\section{Negara, Utopia dan Keterasingan}

Konsep negara dalam sudut pandang pascakolonial sebenarnya sudah lama digaungkan oleh Homi Bhabha dengan bukunya Nation and Narration (1990). Menurut Bhaba, negara atau bangsa merupakan sebuah kesatuan kolektif. Namun, kesatuan kolektif itu sejatinya dipaksakan karena kesatuan kolektif itu menyembunyikan keanekaragaman. Dari konsep inilah para terjajah menyatukan pandangan guna menyingkirkan bangsa penjajah dengan menyebut semua yang terjajah sebagai "kita" dan yang menjajah sebagai "mereka". Lebih lanjut, Bhabha menerangkan bahwa konstruksi kebangsaan yang menyembunyikan keanekaragaman dan menarasikannya akan memunculkan sebuah pengalaman kehidupan 
"di tepi atau di pinggir" sebuah bangsa tersebut. Bagi Bhabha, negara tak ubahnya hanya strategi naratif untuk membuat sebuah identitas dan aparatus pemerintahan (Bhabha, 1990: 292).

Dari apa yang telah disampaikan oleh Bhabha di atas, Upstone mengkonseptualkan negara sebagai sebuah usaha untuk menolak konstruksi teritori yang telah dibangun oleh penjajah. Negara memberikan sebuah penawaran agar dilakukan klaim atas ruang, yang pada awalnya memiliki sifat yang mengandung berbagai perbedaan, dan melihat ruang di luar pemikiran kolonial, dimana ruang menjadilokasi, bukan sebagai negasi atas apa yang telah berlalu sebelumnya. Hal ini jelas memberi gambaran adanya 'transformasi spasial' yang tidak hanya berhenti dalam bentuk perubahan kesadaran, namun mulai ditunjukkan dalam resistensi aktif dan perubahan material (Upstone, 2009: 16). Konsep ini melihat chaos muncul dalam ruang secara konseptual, dan realisasinya dalam wujud material untuk menulis kembali apa yang telah direnggut oleh penjajah.

Konsep-konsep yang telah diterapkan oleh penjajah menutupi realita sebenarnya yang lebih kacau (chaos) pada ruang. Dalam konteks pascakolonial, munculnya kembali kondisi chaos dapat menjadi momentum untuk melakukan re-imajinasi atas ruang. Pemunculan kembali kondisi chaos tersebut bukanlah ditujukan untuk menghilangkan semua stabilitas yang ada, namun lebih pada upaya pemanfaatannya dalam membongkar pandangan yang dianggap tetap dan membangun pola pemahaman dan pengalaman yang baru (Upstone, 2009: 12). Re-imajinasi tentang ruang yang dimanfaatkan oleh negara ini memanglah tidak ditujukan untuk menghilangkan stabilitas yang sudah terbangun. Namun, apa yang dilakukan negara sama dengan para pelaku kolonialisme, yaitu menutupi realita instabilitas yang terjadi di dalam ruang bernegara. Dalam praktik untuk meraih kemerdekaan, negara menggunakan panji-panji persatuan dalam perbedaan. Setelah kemerdekaan, simbol-simbol ini terus dibawa oleh negara guna menjaga stabilitasnya secara interen. Namun kenyataannya, warga negara yang berasal dari berbagai identitas tidaklah sama dan tidak akan pernah sama. Negara mempersatukan mereka dengan halhal simbolik seperti bahasa yang satu dan mempunyai identitas yang sama. Konsep inilah yang menciptakan chaos bagi warga negara yang merasa tidak puas dengan negara, sehingga muncullah sebuah mimpi tentang kota ideal yang ada di luar sana.

Dari chaos yang tercipta itulah terjadi perjalanan menuju tempat yang akan memberikan ruang yang lebih longgar dari pada ruang yang ditawarkan oleh negara. Konsep perjalanan dalam konteks pascakolonial dimulai dari eksporasi ruang yang lebih besar daripada negara atau yang dalam terminologi Upstone disebut dengan "larger than nation". Representasi ruang lebih besar daripada negara dapat dilihat dari motif perjalanan sebagai wujud representasi keterlibatan sebuah ruang yang tak berbatas (Upstone, 2009: 57). Perjalanan merupakan usaha untuk melarikan diri dari batas-batas yang disematkan oleh negara. Perjalanan ini tidaklah sama dengan perjalanan yang dilakukan oleh penjajah untuk menemukan ruang absolut dimana mereka bisa melakukan fiksasi pada ruang tersebut. Perjalanan ini melampaui batas-batas dan pemetaan, sehingga mendekati sesuatu yang jauh lebih cair, tak dapat dijelaskan dan chaos. Perjalanan ini adalah untuk menjelajahi konsep pasca-ruang (Upstone, 2009: 58).

Pasca-ruang di sini adalah ruang yang tidak lagi ada, ruang baru dimana tidak ada praktik-praktik yang muncul dalam ruang sebelumnya. Pasca-ruang sediri bersifat konseptual, sehingga perjalanan yang dilakukan dalam konteks pascakolonial merupakan suatu perjalanan yang tanpa keberangkatan dan tujuan yang final, juga tanpa keinginan untuk bermukim. Perjalanan ini adalah sebuah pergerakan yang diisi dengan potensi gerakan yang stabil dan bersifat chaos (Upstone, 2009: 59). Perjalanan pascakolonial bisa dimulai dengan sebuah perjalanan tetang konsep tempat yang cair dimana tidak ada lagi yang membatasi pergerakan. Dari konsep inilah usaha-usaha 
konkret akan dilakukan untuk menemukan tempat tersebut. Namun, tempat itu sebenarnya tidak ada karena hanya ada dalam konsep, sehingga perjalanan yang dilakukan tidak akan mempunyai satu tujuan yang pasti. Selain itu, keberangkatan perjalanan tersebut dapat juga dilakukan dalam angan-angan, tidak ada sebuah keberangkatan yang terjadi secara fisik, hanya petualangan batiniah yang melakukan perjalanan pada suatu tempat yang diidamkan. Jadi, bisa dikatakan bahwa awal mula perjalanan menjadi kabur atau bahkan tidak pernah terjadi sebuah keberangkatan.

Perjalanan yang dilakukan sebenarnya untuk mencari sebuah kota impian dimana keterbatasan-keterbatasan yang dirasakan di tempat sebelumnya tidak akan pernah ada lagi. Perjalanan memang didasari pada pergerakan pascakolonial yang lebih besar daripada ruang negara. Namun, tujuan dari perjalanan itu adalah sebuah tempat yang lebih kecil daripada negara. Ruang yang lebih kecil itu lazim disebut dengan kota. Kota dalam pengertian ini merupakan representasi dari tensi yang ada di dalam suatu negara atau bangsa. Kota terkait dengan wacana utopis dapat diartikan sebagai ruang urban yang tidak hidup, realitas material, tetapi muncul sebagai mimpi. Meskipun kota utopis muncul dalam berbagai representasi dari kengerian kota industri, namun kota ini juga memproyeksikan keinginan pribadi dan harapan komunal (Upstone, 2009: 85). Kota utopis memang wujud dari harapan berbagai orang yang ingin berpindah ke dalamnya. Namun, kota ini juga menyimpan sebuah kengerian yang merupakan sublimasi dari kengerian negara dimana kota itu berada. Kota utopis ternyata tidak hanya menawarkan sebuah pembebasan, tetapi juga sebuah wujud keterkekangan baru yang mungkin belum ada di dalam tempat yang sebelumnya.

\section{"Keterasingan Tokoh Kakek dalam Gemerlap Utopia} hidup kami

Hidup yang kami jalani bukanlah asing

\author{
Tanah yang kami pijak bukanlah \\ tanah kami \\ Bahasa yang kami ucap bukanlah \\ milik ibu kami \\ Kami bukanlah diri kami \\ Dan semua terjadi karena gerbang \\ itu...." (Taneko, 2013).
}

Keterasingan dalam cerpen ini sudah terbentuk dari awal cerpen ini yang ditandai dengan adanya puisi singkat di atas narasi cerpen ini. Keterasingan dalam cerpen ini dimulai dari kategori keterasingan secara spasial. Kalimat "tanab yang kami pijak bukanlah tanah kami" menunjukkan adanya klaim akan tempat. Kemudian ada dua kategori tempat, yaitu tanah yang milik kami dan tanah yang bukan milik kami. Dalam tanah milik kami, negara melakukan apropriasi untuk menjadikan 'tanah yang menjadi milik kami' tidak asing, tanah yang dimengerti dan dipahami. Di sisi lain, 'tanah yang bukan menjadi milik kami' menjadi tanah yang asing dan antah-berantah, bahkan langit yang menggantung di atas bumi menjadi sesuatu yang lain juga, padahal langit mempunyai kesamaan di setiap kolongnya.

Dari penggalan puisi "dan semua terjadi karena gerbang itu", sudah jelas bahwa semua kekacauan dan keterasingan yang terjadi disebabkan oleh gerbang. Gerbang sejatinya adalah bangunan yang menjadi pintu bagi tembok pembatas yang mengelilinginya. Tembok membatasi tempat yang ada di luar dan juga ruang yang ada di dalam. Gerbang merupakan penengah antara tempat di dalam dan ruang di luar. Hal ini jelas akan memunculkan chaos bagi siapa saja yang ada di gerbang tersebut karena terjadi penumpukan antara tempat yang di dalam dan ruang yang ada di luar. Siapapun yang ada di sana pasti akan melihat dunia sebagai sebuah dunia dengan ruang yang absolut dan kemudian membandingkannya dengan segala keterbatasan yang ada di tempat di dalam tembok. Fantasi-fantasi tentang tempat baru yang dapat menghadirkan sesuatu yang tidak bisa dihadirkan oleh negaralah yang menciptakan tembok itu. Berdasarkan hal itu, "kami" dalam cerita melakukan perjalanan ke 
sebuah tempat di luar tembok yang selama ini mereka tinggali.

Gerbang jugalah yang mengantarkan tokoh kakek dalam ketersesatan. Gerbang dimana chaos terjadi mengantarkan kakek pada sebuah keberangkatan ke tempat lain yang belum pernah dia bayangkan. Gerbang menurut kakek dalam cerpen ini adalah batas rumah dengan tempat asing yang antah-berantah. Rumah yang dimaksud kakek dalam cerpen ini bukanlah sebuah rumah yang sebenarnya, melainkan sebuah metafor dari negara. Negara bagi si kakek merupakan tempat yang aman dan nyaman karena dia merasa bahwa apa yang ada di luar rumah merupakan sesuatu yang asing dan antah-berantah. Selain itu, dalam perjalanannya menuju tempat yang asing itu, dia hanya tertidur dan sesekali membuka matanya. Ini terjadi karena kakek sudah merasa bahwa dirinya sudah tidak nyaman lagi berada di luar tempat dimana ia merasa terikat. Perjalanan kakek ternyata berakhir pada gerbang lain yang juga kemungkinan besar menjadi sebuah pintu bagi tembok lain yang mengelilingi gerbang itu.

"Ketika melalui gerbang itu, saya tak pernah menyangka akan diantar pada dunia yang sungguh asing, Nak,' kakek di sampingku memulai kisah.

'Gerbang itulah batas akhir rumah dengan tempat asing. Kemudian, saya terbang membumbung di angkasa, melampaui samudera dan benua, terkantuk-kantuk hingga kembali bangun, melihat mentari merah sekejap lalu gelap malam sebentar kemudian. Lalu, ratusan lampu jalan dan penanda pendaratan: sebuah gerbang yang lain. Semua yang ada di luar gerbang tak pernah sebelumnya saya lihat. Itulah awal perjalanan panjang saya. Hidup di tanah yang asing. Tak pernah tahu rupa orang-orang yang akan saya temui, seperti apa tempat yang akan saya kunjungi, jalanan yang akan saya lalui, pepohonan yang berdiri di sisinya. Tak pernah dapat menduga bebauan yang akan tercium dan rasa yang akan terkecap. Segalanya sungguh asing, Nak"' (Taneko, 2013).

Secara fisik memang perjalanan tokoh kakek sudah sampai pada tempatnya. Namun, sebenarnya perjalanan kakek barulah dimulai di sini. Jika kakek ingin bertahan dalam dunia yang asing ini, dia haruslah menakhlukkan keterasingannya dalam tempat yang baru saja ia kunjungi ini. Bertahan di lingkungan yang baru dengan tanah, manusia, bahkan bebauan yang asing ini bukan perkara mudah bagi si kakek. Dalam narasinya si kakek berjuang lama guna mengatasi keterasingannya. Hal ini bisa dilihat dari kakek yang digambarkan oleh narator sebagai orang yang sudah memiliki uban dan merasa bahwa dirinya masih berada dalam keterasingan. Kakek merasakan keterasingan karena kakek membuat batasan akan dirinya dan yang di luar dirinya. Sang kakek masih membawa serta pandangan-pandangan tentang ruang dimana dia berasal. Pandangan itu jelas menciptakan ruang baru dan bertindih dengan kota yang menjadi manifestasi dari tempat lain sehingga terjadi chaos.

Kakek akhirnya melakukan perjalanan mengeksplorasi ruang, berharap menemukan tempat yang indah dan tersembunyi. Tujuan perjalanannya sebenarnya sama dengan perjalanan kolonial yang merupakan perjalanan untuk menakhlukkan daerah baru yang asing dan mengklaimnya menjadi ruang milik kolonial. Kakek juga melakukan hal yang hampir sama. Hal ini dapat dilihat dari niat kakek untuk menemukan tempat yang tersembunyi. Tempat tersembunyi adalah tempat yang tidak diketahui lokasinya oleh orang banyak, bahkan dalam narasi kakek menyebutkan bahwa tempat itu belum pernah tertulis di peta manapun. Tempat yang tersembunyi itu biasanya adalah tempat yang tak bertuan, sehingga kakek dapat mengklaim tempat tersebut menjadi miliknya dan mengapropriasi agar ruang tersebut menjadi ruang yang dikenalinya. Hal tersebut dapat dilihat dari kutipan berikut.

"Saya mulai menjelajah tempattempat. Ada kalanya saya membawa peta, kebanyakan hanya berjalan tanpa tujuan, berharap akan berujung pada tempat indah nan rahasia, yang tak ditemui di peta mana pun. Sungguh menyenangkan 
perjalanan saya itu, pada awalnya. Harihari dipenuhi keingintahuan, petualangan baru dan pengembaraan. Namun, yang demikian itu tentu tak akan berlangsung selamanya, Nak" (Taneko, 2013).

Konstruksi ruang dalam cerpen ini digambarkan sebagai kota yangindah dan teratur. Para penduduk kota hanya menggunakan sepeda kayuh sebagai sarana transportasi mereka. Saat kapal melewati jembatan yang terangkat, para pengendara sepeda pun menunggu dengan tertib tanpa ada masalah. Keindahan kota juga ditunjukkan dengan para warganya yang memasang bunga pada keranjang sepeda. Selain itu, keindahan juga nampak dari "lantai" kota yang berwarna-warni karena guguran daun pohon sub-tropis. Dalam kota ini sebenarnya ada ruang-ruang yang bertumpuk. Pertama, kota ini merepresentasikan ruang modernitas dimana jembatan dapat terbelah, selain itu kapal-kapal juga dapat melintas di sungai yang mengalir lurus. Ruang tradisional juga muncul dalam penggambaran ruang kota yang direpresentasikan dengan para penduduk kota yang masih menggunakan kendaraan yang tidak bisa dibilang modern, yaitu sepeda. Kedua, ruang dalam kota ini tidak saling melakukan override, bahkan bisa dikatakan keduanya dapat bersanding satu sama lain. Hal ini ditengarai bahwa kedua ruang yang muncul dalam kota itu tidak bersinggungan satu sama lain, sehingga tidak terjadi chaos. Kedua ruang itu muncul dalam dua hal yang berbeda, moderinitas hanya muncul dalam konteks fasilitas kota, sedangkan hal yang lebih bersifat tradisional muncul dalam gaya hidup warganya. Hal itu dapat dilihat dari kutipan berikut ini.

"Di balik jendela tram, sungai mengalir lurus, rumah-rumah kapal bergoyang. Jembatan terbelah, bergerak naik, membiarkan kapal-kapal lewat. Orang-orang bersepeda, orangtua, orang muda dan anak-anak. Pemuda dengan bunga di dalam keranjang sepeda. Mereka menunggu jembatan kembali datar. Lalu rerumputan, bangkubangku kayu, berselang-seling pokokpokok mapel dan sikamor. Daun-daun berserak, mewarnai hijau rumput: kuning, cokelat, merah" (Taneko, 2013).

Keadaan kota yang seperti inilah yang menjadi feromon bagi para pendatang untuk datang dan menetap di kota ini. Dinarasikan bahwa banyak yang datang di kota ini dan tidak lagi kembali ke asal-usul mereka dengan berbagai alasan, ada pula yang datang secara ilegal dan tertahan untuk pulang. Namun, mengapa si kakek datang ke kota ini seperti dengan unsur keterpaksaan? Para imigran lain datang tanpa keterpaksaan, bahkan betah dan tidak mau pulang, sedangkan si kakek malah merasa terasing dengan ruang-ruang yang ditawarkan oleh kota dalam cerpen ini. Dalam narasi selanjutnya si kakek diceritakan tidak bisa pulang dan beasiswanya dicabut. Perjalanan panjang si kakek pun akhirnya harus berhenti sejenak. Kakek akhirnya juga harus bekerja dan bermukim seperti orangorang kebanyakan. Namun, si kakek kesulitan mendapatkan pekerjaan. Hal itu terjadi karena penguasaan bahasa Belanda kakek yang masih terbata-bata. Penggunaan bahasa Belanda sebagai bahasa yang lazim digunakan dalam dunia kerja menjadi kerangkeng yang sangat membatasi ruang gerak si kakek. Selain itu, perbedaan spesifikasi pendidikan juga menjadi rantai yang mengungkung tokoh kakek dalam cerpen ini. Padahal dalam cerpen diceritakan bahwa kakek mendapatkan beasiswa dan dapat menempuh pendidikan sampai ke negeri Belanda. Kakek di sini pastilah bukan orang yang pandir ataupun orang dengan pendidikan yang rendah. Pendidikan yang disematkan oleh negara asal si kakek, yakni Indonesia, malah membatasi ruang gerak kakek di dalam kota yang utopis seperti kota Delft dalam cerita.

Kota dalam konteks pascakolonial seperti dalam paparan teori di atas merupakan representasi dari tensi yang ada di dalam suatu negara. Praktik-praktik politik spasial kenegaraan juga diwujudkan dalam penataan ruang kota. Kota Delft yang merupakan kota utopis dalam cerita ternyata menyimpan kengerian yang luar biasa akan persaingan 
dunia kerja. Dari penggambaran tetang ruang kota yang sudah disebut di atas sepertinya tidak ditemukan kengerian di dalamnya, bahkan yang muncul adalah keteraturan dan keindahan. Di balik itu semua kota Delft merupakan kota metropolis yang modern, tidak mudah untuk bisa bertahan di sana. Perusahaan-perusahaan yang berdiri di sana pastilah merupakan perusahaan besar yang mematok standar yang sangat tinggi dalam penerimaan pekerja. Jika tidak bisa bertahan, maka akan terpinggirkan dan terkotak dalam keterasingan seperti tokoh kakek dalam cerpen ini. Penjelasan ini dapat dilihat dari kutipan berikut ini.

"Sejak saya mendapat izin kerja, saya mati-matian mencari pekerjaan. Tidak mudah, Nak. Dengan bahasa Belanda yang terbata-bata dan kualifikasi pendidikan yang berbeda, tak ba n y a k pilihan pekerjaan bisa saya lamar. Sempat saya kehabisan uang, tak mampu bayar kamar sewa, hingga menumpang di penampungan tuna wisma" (Taneko, 2013).

Kakek akhirnya pun harus terpinggirkan dalam ruang kota yang sebenarnya luas, modern, dan indah. Si Kakek harus tinggal di sebuah loteng rumah bedeng, dengan kamar yang sangat sempit, dan hanya seluas bentangan tangan. Pada saat sulit, dia bahkan harus tinggal di penampungan tuna wisma. Meskipun Belanda memberikan tunjangan bagi tuna wisma dan orang miskin seperti tokoh kakek dalam cerita, dia tidak mau menerima tunjangan tersebut karena merasa gengsi dihidupi oleh negara lain yang bukan merupakan tanah airnya sendiri. Cengkraman nasionalitas sangatlah kuat menggenggam kakek. Harga diri sebagai orang yang pernah terjajah menciptakan ruang yang membelenggu kakek.

Gerbang yang dimaksud dalam cerpen ini adalah pendidikan. Karena dalam cerpen ini, kakek dan Ito (narator) merupakan mahasiswa atau pelajar yang mendapatkan beasiswa studi ke luar negeri. Pendidikan sejatinya membuka mata bagi orang yang dibutakan oleh ketidaktahuan. Pendidikan yang diterima tokoh dalam cerpen ini membuka sebuah kesadaran tentang ruang yang lebih luas daripada negara. Dari situlah muncul gambaran-gambaran tentang sebuah tempat lain yang mungkin dapat menawarkan sesuatu yang lebih dari apa yang ditawarkan oleh negara. Namun, tokoh kakek sepertinya terpaksa untuk memenuhi beasiswa tersebut. Hal itu terlihat dari betapa beratnya ia meninggalkan Indonesia. Tokoh kakek sepertinya dipaksa oleh negara untuk melanjutkan studinya ke luar negeri. Negara juga memasang "rantai" kepada tokoh kakek dengan kecintaan terhadap tanah air, agar setelah mendapatkan ilmu yang bermanfaat di negeri orang, dia akan kembali ke Indonesia.

\section{Kesimpulan}

Tokoh kakek dalam cerpen ini merasa terasing di kota utopis karena kecintaan terhadap tanah air yang disematkan kepadanya. Apapun yang bukan menjadi bagian dari tanah airnya menjadi sesuatu yang asing dan aneh. Awal dari perjalanan tokoh kakek menuju ke sebuah kota utopis adalah karena sebuah gerbang yang chaos dimana ruang negara dan ruang absolut di luar saling tumpuk. Kota utopis yang dituju seperti Den Haag dan Delft sebenarnya kota yang menyimpan keindahan di mana ruang modern dan tradisional dapat bersandingan tanpa bersinggungan satu sama lain. Namun, seperti kota utopis lainnya, kota ini juga merupakan manifestasi dari negara di mana kota itu berdiri. Negara Belanda yang kaya dan modern telah membuat "kotak" bagi spesifikasi pendidikan pekerja yang ada di sana. Hal ini membuat tokoh kakek yang mempunyai spesifikasi pendidikan yang berbeda menjadi kian terpinggirkan dan terkotak dalam suatu ruang yang besarnya hanya sebentangan tangan. 
Jurnal Poetika Vol. II No. 2, Desember 2014

\section{Daftar Pustaka}

Bhabha, Homi K. 1990. Nation and Narration. London: Routledge

Salam, Aprinus. 2003. "Identitas dan Nasionalitas dalam Sastra Indonesia" dalam Jurnal Humaniora Volume XV, No. 1, Jakarta

Upstone, Sara. 2009. Spatial Politics in The Postcolonial Novel. England: Ashgate Publishing Limited.

Taneko, Rilda A.Oe. 2013. "Antara Den Haag dan Delft". Koran Tempo. 